\title{
Research Paper: The Study of Affecting Factors on Attitude Toward Hearing Loss in Hearing Aid Users and Hearing Aid Non-Users
}

\author{
Parisa Heidari $^{1}$ (D) Farzaneh Fatahi $^{{ }^{*}}$ (D), Reza Hoseinabadi', Nematollah Rouhbakhsh ${ }^{1}$
}

1. Department of Audiology, School of Rehabilitation, Tehran University of Medical Sciences, Tehran, Iran.

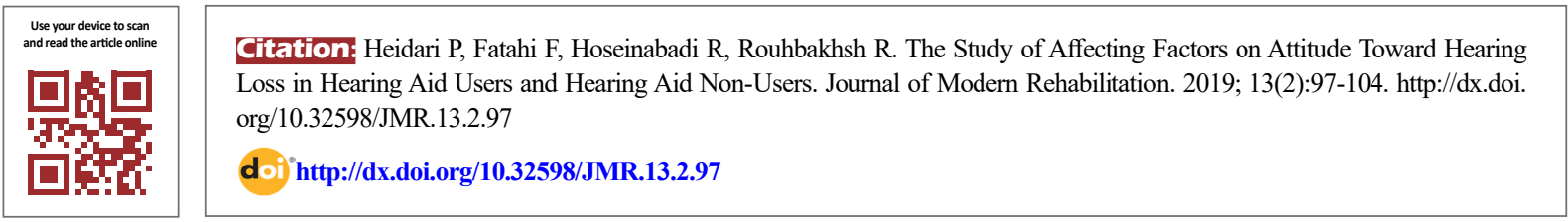

Article info:

Received: 09 Aug 2018

Accepted: 23 Jan 2019

Available Online: 01 Apr 2019

\section{Keywords:}

Hearing aids, Hearing loss, Attitude, Questionnaire

\section{ABSTRACT}

Introduction: Attitudes and aptitudes play an important role in the acceptance of hearing aids. We can objectively and subjectively examine the attitude of individuals toward hearing loss and hearing aids, using Attitudes towards Loss of Hearing Questionnaire (ALHQ). The aim of this study was to examine the effect of demographic factors on the responses of individuals to ALHQ and to compare the scores of the questionnaire between hearing aid users and hearing aid non-users.

Materials and Methods: This study was performed on 100 hearing-impaired participants They were divided into hearing aid users and non-users groups. After hearing assessments, the participants were asked to complete the questionnaire; then, the responses of the two groups were compared and the effects of demographic factors on the responses were examined.

Results: The questionnaire scores in the hearing aid non-users were higher than the hearing aid users. The results showed a reverse correlation between the history of hearing aid usage and the scores of the questionnaire. There was also a reverse correlation between the mean score of pure tone thresholds in the left ear with the scores of the questionnaire in the hearing aid users. Furthermore, there was a significant correlation between the type of hearing aid and the scores of the questionnaire.

Conclusion: Hearing aid non-users have a more negative attitude toward hearing aids and are more likely to deny their hearing loss compared to hearing aid users.

\section{Introduction}

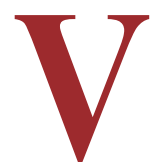

arious studies have shown that only $14 \%$ to $31 \%$ of those who have hearing loss use hearing aids $[1,2]$ and the people's perception of their hearing problems and the motivation to do something to resolve those problems strongly predicted the amount of hearing aid usage [3]. Previous studies showed increment in hearing aid usage with increasing age and the severity of hearing loss so that younger people and people with milder hearing loss had the least hearing aid usage [4]. The low-frequency

* Corresponding Author:

Farzaneh Fatahi, PhD.

Address: Department of Audiology, School of Rehabilitation, Tehran University of Medical Sciences, Tehran, Iran.

Tel: +98 (21) 77530636

E-mail:jfatahi@tums.ac.ir 
use of hearing aids in the elderly could be because of the lack of awareness of hearing problems, stigma, problems of working with hearing aids, or the lack of awareness of the benefits of hearing aids $[5,6]$.

One of the main reasons that people decide to stop using hearing aids is the stigma of wearing hearing aids [7]. In fact, $48 \%$ of people with hearing loss, who do not use hearing aids, declare that it is because of the stigma of hearing aids [8]. Another reason for refusing the use of hearing aids is the denial of hearing loss. Two-thirds of people with hearing loss went on to develop a selfperceived hearing handicap within 5 years after the diagnosis of hearing loss [9]. However, with the increment of the degree of hearing loss, the number of hearing-impaired people, who use hearing aids, and hours of using it per day increases [10].

Individuals' attitudes and beliefs play an important role in accepting the usage of hearing aids [11]. Through questionnaires, we can objectively examine the attitudes of people toward hearing loss and hearing aids. Questionnaires can also be used to examine the changes in attitudes of individuals over time and in the clinic, they can help clinicians to understand the personality traits that affect people's attitudes [12]. One of these questionnaires is Attitudes towards Loss of Hearing Questionnaire (ALHQ) published by Saunders and Cienkowski [13] and translated into Persian by Heidari et al. [14]

This questionnaire consists of 22 questions, including the subscales of denial of hearing loss, negative associations, negative coping strategies, manual dexterity, and vision and hearing-related esteem. It takes 10 minutes to answer its questions and the total score of the questionnaire is considered as the scores of the attitude of hearing loss and higher scores indicate a more negative attitude toward hearing loss. ALHQ helps clinicians to recognize the harmful attitudes of people and properly consult them according to their needs [15]. The aim of this study was to examine the effect of demographic factors on the responses of individuals to ALHQ and to compare the scores of the questionnaire between two groups of hearing aid users and hearing aid non-users.

\section{Materials and Methods}

This descriptive-analytical study was performed on 100 hearing-impaired patients referred to the Audiology Clinic of Tehran University of Medical Sciences. Individuals were divided into two groups; group 1 consisted of hearing aid users and group 2 consisted of hearing aid non-users and each group included 50 indi- viduals. The inclusion criteria included sensory hearing loss, the age range of 30 to 65 years, the absence of effusion and active otitis media (no conductive loss), and the absence of neurological and otological diseases. The exclusion criteria consisted of fatigue and reluctance to continuing research for any reason and the loss of any of the inclusion criteria.

Initially, the aim of this study was explained to the individuals and we took a case history of all participants we also did otoscopy examination (for examining the presence of ear wax) and tympanometry to assess tympanic membrane and middle ear status, and Pure Tone Audiometry (PTA), which is the most common test for assessing auditory sensitivity at different frequencies [16]; then, all participants were asked to answer the translated version of the ALHQ (Appendix). Finally, the responses of the two groups were compared and the effect of the demographic data on the responses of both groups was evaluated.

The data were analyzed, using SPSS 23 and nonparametric tests, including the Mann-Whitney U test, Kruskal Wallis test, and Spearman were used for data analysis. Moreover, $\mathrm{P}<0.05$ was considered as the level of significance.

\section{Results}

The number of participants in this study was 100, including 52 males and 48 females, representing $52 \%$ and $48 \%$ of the sample size, respectively. The mean age of the subjects participating in the study was 54.54 with a Standard Deviation (SD) of 12.05 years and a minimum age of 30 and a maximum of 65 years. Table 1 presents the characteristics of the participants.

The results of PTA showed that Mean \pm SD PTA threshold in the hearing aid users was $48.58 \pm 12.01 \mathrm{~dB}$ HL in the right ear and $48.19 \pm 10.98 \mathrm{~dB}$ HL in the left ear; these values in the right and left ears of the hearing aid nonusers were $41.73 \pm 19.40$ and $43.20 \pm 17.62$, respectively.

Statistical analysis showed a significant difference between the mean PTA thresholds in groups 1 and 2 in the right ear $(\mathrm{P}=0.002)$ and left ear $(\mathrm{P}=0.017)$; the results also indicated that pure tone thresholds in both ears in group 1 were worse than participants in group 2.

Table 2 presents the analysis of the questionnaire scores totally and in each of the subscales in both groups. The scores of the questionnaire were higher in group 2 than in group 1, which indicates that people, who do 
Table 1. Demographic characteristics of the subjects in group 1 and $2(n=5)$

\begin{tabular}{|c|c|c|c|c|}
\hline \multirow{2}{*}{\multicolumn{2}{|c|}{ Variables }} & \multicolumn{2}{|c|}{ Mean $\pm S D$, No. (\%) } & \multirow{2}{*}{$\mathbf{P} *$} \\
\hline & & 1 & 2 & \\
\hline \multicolumn{2}{|l|}{ Age (year) } & $56.68 \pm 11.89$ & $52.40 \pm 11.94$ & 0.076 \\
\hline \multirow{2}{*}{ Sex } & Male & $24(48)$ & $28(56)$ & \multirow{2}{*}{0.274} \\
\hline & Female & $26(52)$ & $22(44)$ & \\
\hline \multirow{2}{*}{ Otologic and neuroligic disease } & Have & $4(8)$ & $46(92)$ & \multirow{2}{*}{0.370} \\
\hline & Have not & $6(12)$ & $44(88)$ & \\
\hline \multicolumn{2}{|c|}{ History of using hearing aids (month) } & $\begin{array}{c}29.52 \pm 43.31 \\
(1-180)\end{array}$ & - & - \\
\hline \multicolumn{2}{|c|}{ Duration of using per day (hours) } & $\begin{array}{c}8.40 \pm 5.37 \\
(2-18)\end{array}$ & - & - \\
\hline \multirow{3}{*}{ Mode of hearing aids } & Right ear & $20(40)$ & \multirow{3}{*}{-} & \multirow{3}{*}{-} \\
\hline & Left ear & $20(40)$ & & \\
\hline & Binaural & $10(20)$ & & \\
\hline \multirow{3}{*}{ Hearing aids in right ear } & BTE & $12(24)$ & \multirow{3}{*}{-} & \multirow{3}{*}{-} \\
\hline & ITE & $14(28)$ & & \\
\hline & RIC & $4(8)$ & & \\
\hline \multirow{3}{*}{ Hearing aids in left ear } & BTE & $22(44)$ & \multirow{3}{*}{-} & \multirow{3}{*}{-} \\
\hline & ITE & $8(16)$ & & \\
\hline & RIC & $0(0)$ & & \\
\hline
\end{tabular}

RIC: Receiver-in-Canal; ITE: In the Ear

* Significant correlation is at the level of 0.05 .

not use hearing aids, have a more negative attitude toward it. There was a significant difference between the two groups in the subscale of denial of hearing loss $(\mathrm{P}=0.000)$, manual dexterity and vision $(\mathrm{P}=0.044)$, and hearing-related esteem $(\mathrm{P}=0.007)$. The scores of denial of hearing loss were higher in group 2, whereas the scores of manual dexterity and vision and hearing-related esteem were higher in group 1.
The results of the correlation between the quantitative variables and the scores of the questionnaire in the both groups indicate that in group 1, there is a reverse correlation between the history of hearing aid usage $(\mathrm{P}=0.010)$ and the mean pure tone thresholds in the left ear $(\mathrm{P}=0.002)$ with the scores of the questionnaire; the individuals with longer hearing aids usage had better attitudes toward it and those who had a better hearing threshold in the left ear had a worse attitude toward hearing aids. However, there was no correlation among

Table 2. Mean $\pm S D$ of ALHQ subscales and total score in group 1 and $2(n=50)$

\begin{tabular}{|c|c|c|c|}
\hline \multirow{2}{*}{ Subscales } & \multicolumn{2}{|c|}{ Mean $\pm S D$} & \multirow{2}{*}{ P* } \\
\hline & 1 & 2 & \\
\hline Denial of hearing loss & $4 \pm 13$ & $5 \pm 17$ & $P<0.001$ \\
\hline Negative associations & $5.03 \pm 11$ & $4 \pm 12$ & 0.088 \\
\hline Negative coping strategies & $3 \pm 20$ & $6.05 \pm 20$ & 0.319 \\
\hline Manual dexterity and vision & $3 \pm 5$ & $2 \pm 4$ & 0.044 \\
\hline Hearing-related esteem & $20.03 \pm 7$ & $2 \pm 6$ & 0.007 \\
\hline Total & $11 \pm 59$ & $8 \pm 61$ & 0.038 \\
\hline
\end{tabular}

* Significant correlation is at the level of 0.05 . 
Table 3. Correlations between the mean score of ALHQ and type of hearing aid

\begin{tabular}{|c|c|c|c|c|}
\hline Ear & Hearing Aid & Number & Mean士SD & P* \\
\hline \multirow{5}{*}{ Right } & BTE & 12 & $60 \pm 12.29$ & \multirow{5}{*}{0.616} \\
\hline & RIC & 14 & $59 \pm 0$ & \\
\hline & & & & \\
\hline & ITE & 4 & $62 \pm 17.05$ & \\
\hline & Total & 30 & $61 \pm 13.78$ & \\
\hline \multirow{5}{*}{ Left } & BTE & 22 & $55.27 \pm 7.13$ & \multirow{5}{*}{0.023} \\
\hline & RIC & 0 & - & \\
\hline & & & & \\
\hline & ITE & 8 & $73.50 \pm 15.50$ & \\
\hline & Total & 30 & $60.13 \pm 12.72$ & \\
\hline
\end{tabular}

RIC: Receiver-in-Canal; ITE: In the Ear

* Significant correlation is at the level of 0.05 .

age, duration of hearing aids usage per day, average pure thresholds in the right ear, and the scores of the questionnaire. Furthermore, there was no correlation between any of these quantitative variables and the scores of the questionnaire in the participants in group 2.

Statistical analysis showed a significant difference between the type of hearing aid and ALHQ scores in group $1(\mathrm{P}=0.023)$. There was no significant correlation between ALHQ scores and gender, having a neurologic and otologic disease and mode of hearing aid in the studied population. Table 3 presents the results of the relationship between the type of hearing aid and the mean scores of the questionnaire in both ears. There was no correlation between the type of hearing aids and the mean scores of the questionnaire in the right ear; but, a significant relationship was found in the left ear $(\mathrm{P}=0.023)$ so that individuals with Behind The Ear (BTE) hearing aids had lower scores and better attitudes toward hearing aids.

\section{Discussion}

In the present study, pure tone thresholds were significantly different between the two groups in the right and left ears so that pure tone thresholds in hearing aids users were higher in both ears. In the study by Saunders et al., pure tone thresholds were also worse in people, who used hearing aids [15], which is consistent with the results of this study.

The results of the study also showed that the scores of the questionnaire were higher in group 2 than group 1, indicating that people, who do not use the hearing aid, have a worse attitude toward hearing aids.
Also, there was a significant difference between the subscales of denial of hearing loss, manual dexterity and vision, and hearing-related esteem between the two groups; so, people who did not use hearing aids had more denial of hearing loss, while the subscales of manual dexterity and vision and hearing-related esteem were higher in group 1. Study of Saunders et al. also showed that the average total score of the questionnaire is higher in people, who do not use hearing aids, resulting in a worse attitude toward hearing aids, and more likely to deny their hearing loss; those who had better hearing thresholds had better hearing-related esteem that is inconsistent with the results of the present study [15].

The high score in the subscale of denial of hearing loss denotes that a person does not view his hearing as a problem and does not feel the need for hearing aids. Studies have shown that even when hearing loss, age, and gender are calculated, those with fewer disabilities are more likely to reject using hearing aids than those who report more disabilities [17]. Therefore, the high score in this subscale is likely to result in low hearing aid usage.

The results showed that in group 1, there was a significant reverse relationship between the history of using hearing aids and the mean of pure tone thresholds in the left ear with the scores of the questionnaire; thus, people who had long history of hearing aid usage had a better attitude and those who had better hearing thresholds in the left ear had a worse attitude toward hearing aids. However, there was no correlation between the other quantitative variables and the scores of the questionnaire. There was a significant difference between the type of hearing aid and the ALHQ scores in group 1 and this 
correlation was seen only in the left ear and those who used BTE hearing aids had lower average scores and, therefore, better attitude. No significant relationship was found between the other qualitative variables and the questionnaire scores.

The results of a study by Jo et al. show that the demographic factors, such as gender, age, and length of the usage of the hearing aid had no effect on the scores of the questionnaire [18]. In a study by Bastos et al., no association was found between demographic data, auditory thresholds, and ALHQ scores [19].

The results of Saunders et al.'s study indicated a direct association between better hearing and older age with more denial of hearing loss; youth and male gender were related to the higher score of negative association subscale; weaker hearing, youth, and female gender were associated with the more usage of negative coping strategies. Also, lower hearing-related esteem was associated with weaker hearing, and the subscale of manual dexterity and vision was not associated with any of the independent variables [15].

The differences observed between various studies can be the result of differences in the studied populations and the characteristics of the subjects, such as cultural differences or underlying diseases and abnormalities, such as vision problems, hand tremors, depression, etc.

As the most important limitations of the present study, some questions had been ignored or left unanswered or the participants might not be truthful with their answers. These limitations were largely eliminated by increasing the sample size and explaining the purpose of the study and its importance in managing hearing loss for participants. It is suggested to examine the effects of counseling on people's responses to the questionnaire in the future studies.

The results of this study showed that hearing aid users had worse hearing thresholds than hearing aid non-users. Moreover, hearing aid non-users had a more negative attitude toward it and more likely denied their hearing loss, while hearing aid users showed more problems in the subscales of manual dexterity and vision and hearingrelated esteem. It is recommended to use the quality of life questionnaires along with the ALHQ questionnaire in future studies to assess the relationship between attitudes toward the loss of hearing and quality of life.

\section{Ethical Considerations}

\section{Compliance with ethical guidelines}

This study was approved by the Ethics Committee of Tehran University of Medical Sciences (Code: IR.TUMS. FNM.REC.1397.146).

\section{Funding}

This study is a part of the Master's Degree thesis of Parisa Heydari at the Faculty of Rehabilitation, Tehran University of Medical Sciences.

\section{Authors contributions}

Designed and performed the measurements and cowrote the manuscript: Parisa Heidari; Planning and Supervisioin: Reza Hoseinabadi; Statistical analyses: Nematollah Rouhbakhsh.

\section{Conflict of interest}

The authors declared no conflicts of interest.

\section{References}

[1] Chen X, Liu S, Kong Y, Liu B, Mo L, Liu H, et al. [The characteristics and development of auditory skill for infants with different age after cochlear implantation (Chinese)]. Lin Chuang Er Bi Yan Hou Tou Jing Wai Ke Za Zhi. 2009; 23(4):148-50. [PMID]

[2] Hesse G. [Hearing aids in the elderly. Why is the accommodation so difficult? (German)]. Hrvatski Narodni Odbor. 2004; 52(4):321-8. [DOI:10.1007/s00106-004-1058-4] [PMID]

[3] Libby Harricks. Memorial oration deafness Forum of Australia [Internet]. 2006, pages 4-47. Available from: https:// docplayer.net/102907513-Libby-harricks-memorial-orationthe-honouring-the-deafness-forum-s-first-president-profoundly-deaf-achiever.html.

[4] Chien W, Lin FR. Prevalence of hearing aid use among older adults in the United States. Archives of Internal Medicine. 2012; 172(3):292-3. [DOI:10.1001/archinternmed.2011.1408] [PMID] [PMCID]

[5] Knudsen LV, Öberg M, Nielsen C, Naylor G, Kramer SE Factors influencing help seeking, hearing aid uptake, hearing aid use and satisfaction with hearing aids: A review of the literature. Trends in Amplification. 2010; 14(3):127-54 [DOI:10.1177/1084713810385712] [PMID] [PMCID]

[6] Meyer C, Hickson L. What factors influence help-seeking for hearing impairment and hearing aid adoption in older adults? International Journal of Audiology. 2012; 51(2):66-74 [DOI:10.3109/14992027.2011.611178] [PMID] 
[7] Preminger JE. Issues associated with the measurement of psychosocial benefits of group audiologic rehabilitation programs. Trends in Amplification. 2007; 11(2):113-23. [DOI:10.1177/1084713807301084] [PMID] [PMCID]

[8] Kochkin S. MarkeTrak VII: Obstacles to adult non-user adoption of hearing aids. The Hearing Journal. 2007; 60(4):2451. [DOI:10.1097/01.HJ.0000285745.08599.7f]

[9] Gopinath B, Hickson L, Schneider J, McMahon CM, Burlutsky G, Leeder SR, et al. Hearing-impaired adults are at increased risk of experiencing emotional distress and social engagement restrictions five years later. Age and Ageing. 2012; 41(5):618-23. [DOI:10.1093/ageing/afs058] [PMID]

[10] Bertoli S, Staehelin K, Zemp E, Schindler C, Bodmer D, Probst R. Survey on hearing aid use and satisfaction in Switzerland and their determinants. International Journal of Audiology. 2009; 48(4):183-95. [DOI:10.1080/14992020802572627] [PMID]

[11] Wilson C, Stephens D. Reasons for referral and attitudes toward hearing aids: Do they affect outcome? Clinical Otolaryngology \& Allied Sciences. 2003; 28(2):81-4. [DOI:10.1046/ j.1365-2273.2003.00669.x] [PMID]

[12] Emmett SD, Francis HW. The socioeconomic impact of hearing loss in U.S. adults. Otology \& Neurotology. 2015; 36(3):545-50. [DOI:10.1097/MAO.0000000000000562] [PMID] [PMCID]

[13] Saunders GH, Cienkowski KM. Refinement and psychometric evaluation of the attitudes toward loss of hearing questionnaire. Ear and Hearing. 1996; 17(6):505-19. [DOI:10.1097/00003446-199612000-00006] [PMID]

[14] Heidari P, Fatahi J, Hoseinabadi R, Rouhbakhsh N, Dabiri Satri S, Saunders GH, et al. Persian version of Attitudes towards Loss of Hearing Questionnaire. Auditory and Vestibular Research. 2019; 28(2):124-33.

[15] Saunders GH, Cienkowski KM, Forsline A, Fausti S. Normative data for the Attitudes towards Loss of Hearing Questionnaire. Journal of the American Academy of Audiology. 2005; 16(9):637-52. [DOI:10.3766/jaaa.16.9.2] [PMID]

[16] Qureishi A, Garas G, Mallick A, Parker D. The psychosocial impact of hearing aids in children with otitis media with effusion. The Journal of Laryngology and Otology. 2014; 128(11):972-5. [DOI:10.1017/S0022215114002163] [PMID]

[17] Humes LE, Wilson DL, Humes AC. Examination of differences between successful and unsuccessful elderly hearing aid candidates matched for age, hearing loss and gender. International Journal of Audiology. 2003; 42(7):432-41. [DOI:10.3109/14992020309080053] [PMID]

[18] Jo BH, Shin EY, Kim JS. A study of validity for psychometric evaluation using Attitude toward Loss of Hearing Questionnaire (ALHQ) for the hearing impaired. Audiology. 2011; 7(1):19-27. [DOI:10.21848/audiol.2011.7.1.19]

[19] Bastos BG, Amorim RB, Ferrari DV. [Attitudes towards Hearing Aids (Portuguese)]. Revista CEFAC. 2009; 11(Suupl. 1):116-28. [DOI:10.1590/S1516-18462009005000018] 


\section{Appendix:}

برسشنامه نكَرش نسبت به كم شنوايى (ALHQ) براى افرادى كه از سمعك استفاده نمى كنند.

\begin{tabular}{|c|c|c|c|c|c|}
\hline كاملاً موافقه & 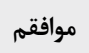 & نه موافقم نه مخالف & 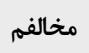 & كاملاً مخالفم & 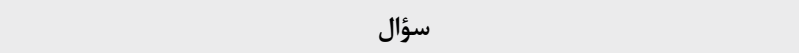 \\
\hline$ه$ & s & ج & ب & الف & ا. صحبت كردن با من براى خانواده و دوستانم سخت است. \\
\hline$\rightarrow$ & د & ج & ب & الف الف & ז. مطمئن هستم براى شنيدن تا حدودى نياز به كمك دارم. \\
\hline$ه$ & s & ج & ب & الف & r. مشكل شنوايى من خيلى كمتر از آن است كه نياز به سمعك داشته باشم. \\
\hline$\rightarrow$ & s & ج & ب & الف & f. تصضور استفاده ازسمعك به من احساس پِيرى مى دهد. \\
\hline$\rightarrow$ & s & ج & ب & 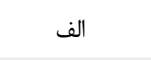 & هـ اتر در موقعيتى قرار بََيرم كه هند نفر در حال صحبت كردن باشند، كفتخَو را رها مى كنم. \\
\hline$ه$ & s & ج & ب & 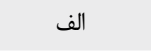 & 9. ميزان اعتماد به نفسم به اندازه زمانى است كه شنوايى من طبيعى بود. \\
\hline$\rightarrow$ & s & ج & ب & 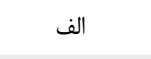 & V. Vاملاً مطمئن هستم كه به سمعك نياز ندارم. \\
\hline$\rightarrow$ & د & ج & ب & 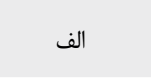 & ــ اين روزها انجام كارهاى ظريفى ماند بستن دكمه و زيب لباس براى من بسيار دشوار \\
\hline$\rightarrow$ & د & ج & ب & 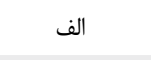 & 9. نكَران زمانى هستم كه مردم ببينند در كوش من سمعك هست. \\
\hline$ه$ & د & ج & ب & 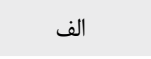 & • . ا. از زمانى كه كمشنوا شدام، از ملاقات با افراد جديد واهمه دارم. \\
\hline$\rightarrow$ & د & ج & ب & 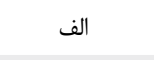 & 11. إمعك باعث مىشود افراد ييرتر به نظر برسند. \\
\hline$\rightarrow$ & د & ج & $\varphi$ & 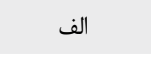 & ا r ا. شنوايى ضعيف من باعث مىشود كه احساس ناكارآمدى كنه. \\
\hline$\rightarrow$ & د & ج & ب & 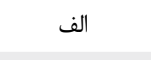 & ا. كمشنوايى من مشكل مهمى نيست. \\
\hline هـ & د & ج & ب & 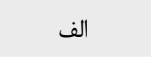 & أ ا. فكر مى كنم با كذاشتن يِيج هاى كوحك در جاى خود مشكل دارم. \\
\hline هـ & د & ج & ب & 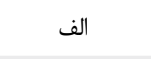 & ها ا. من در هنكام كَفتكو معمولاً ساكت هستم تا مطلبى را اشتباه نكويمه. \\
\hline هـ & د & ج & ب & 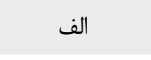 & 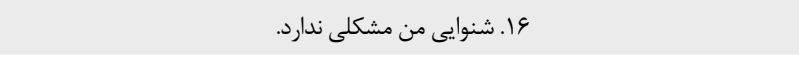 \\
\hline هـ & د & ج & ب & 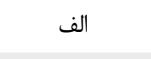 & V V. به علت مشكلات شنوايى، سعى مى كنم از صحبتهاى كوتاه دورى كنه. \\
\hline$\rightarrow$ & د & ج & ب & 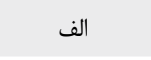 & 11 1. از تصور اين كه مردم مرا با سمعك ببينند، خجالت مىكشم. \\
\hline$\rightarrow$ & د & ج & 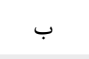 & 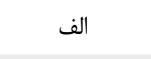 & 19. مشكل شنوايى بارى بر دوش من است. \\
\hline$\rightarrow$ & د & ج & ب & 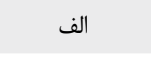 & • • ا. اشياى كوخى خيلى راحت از دستم مىافتند. \\
\hline$\rightarrow$ & د & ج & ب & 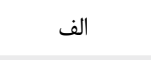 & ا r. همانند قبل از كمشنوايى، اجتماعى و خوشصحبت هستم. \\
\hline هـ & د & ج & ب & 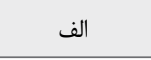 & rr. همواره متوجه هستم كه حس شنوايى من جقدر ضعيف است. \\
\hline
\end{tabular}

\begin{tabular}{|c|c|c|c|c|c|}
\hline كاملاً موافقم & 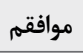 & 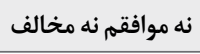 & 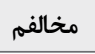 & كاملاً مخالفم & 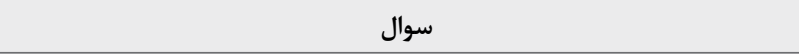 \\
\hline$\rightarrow$ & o & ج & ب & 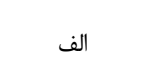 & Y. كمشنوايى من به حدى خفيف است طورى كه به خوبى و بدون استفاده از سمعك مى توانم \\
\hline$\rightarrow$ & د & ج & ب & 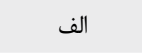 & †. أ. استفاده از سمعك باعث مىشود احساس كنم پِيرتر هستم. \\
\hline$\rightarrow$ & o & ج & ب & 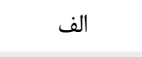 & V. واقعا فكر نمى كنم به سمعك نيازى داشته باشم. \\
\hline$\rightarrow$ & د & ج & ب & 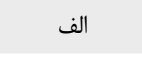 & 9. دوست ندارم ديخران مرا با سمعك ببينند. \\
\hline هـ & د & ج & ب & الف الف & 11. وقتى در حال استفاده از سمعك ديده مىشوم، خجالت مى كشم. \\
\hline
\end{tabular}


نحوه امتيازدهى امتياز سؤالاتى كه با ستاره مشخص شده اند (سؤال او r) را به صورت معكوس محاسبه كنيد.

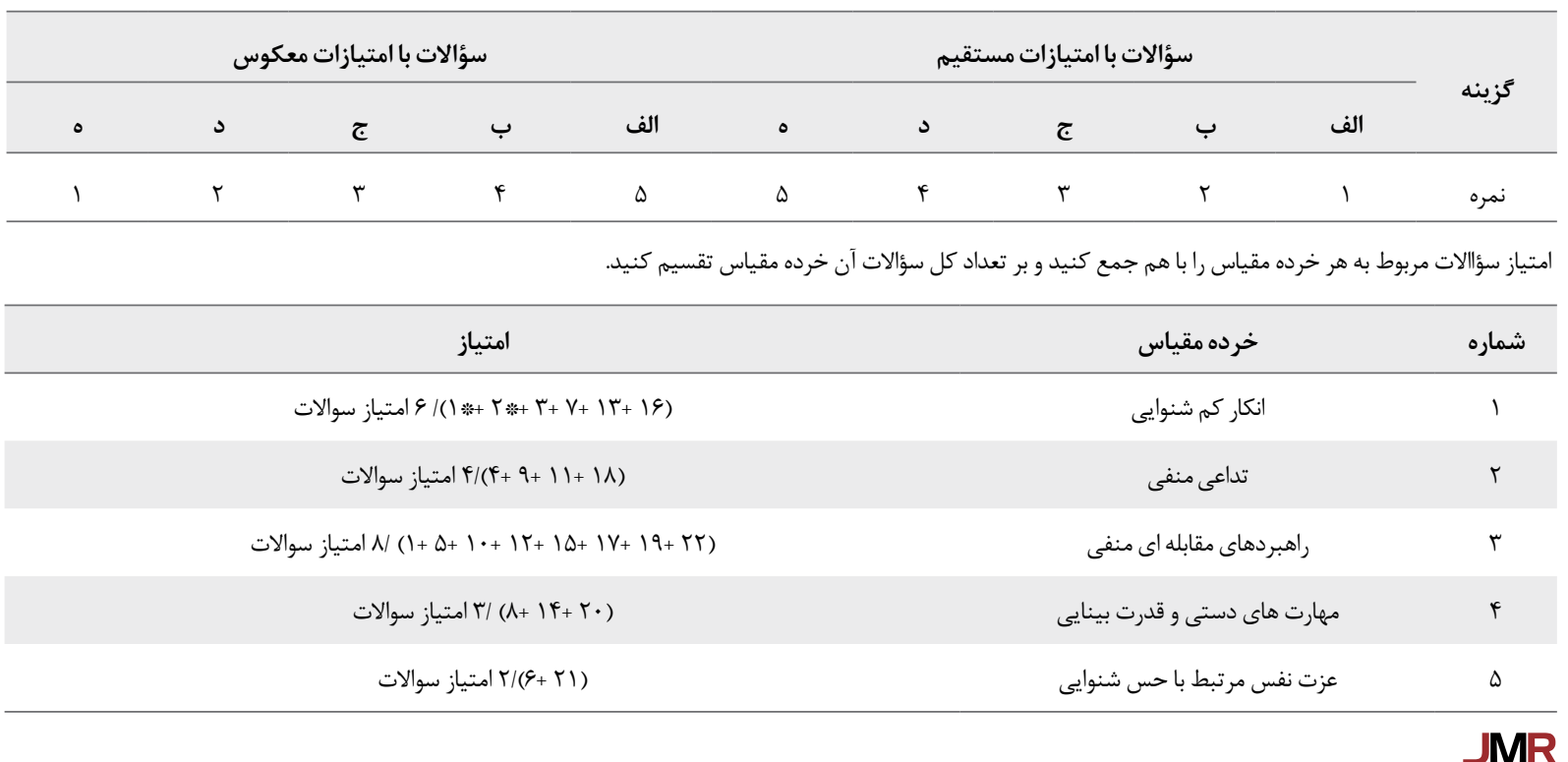

